\title{
THE EVOLUTION OF SERVILE PEASANTS IN HUNGARY AND IN CATALONIA: \\ A COMPARISON
}

\author{
PAUL FREEDMAN \\ Vanderbilt University \\ (USA)
}

\section{CONTENTS}

1. The Hungarian Insurrection of 1514.- 2. Catalonia and Hungary.- 3. Serfdom.- 4. Eastern and Western Europe.- 5. Historical Mythology and the Origins of Social Differentiation.- 6. Historical Myths and Ideological Purpose.

The uprising of the Catalan servile peasants (remences) between 1462 and 1486 was unusual in the history of European insurrections. Waged by a surprisingly well-armed force of peasants who played an important military role as supporters of the king, it resulted in the first official abolition of peasant servitude with the Sentencia Arbitral de Guadalupe. Part of the complex political background to the conflict was an ideological contradiction within the ruling classes of Catalan society, first perceptible in the late thirteenth century, in which legal and historical justifications for servitude were opposed by assertions that it violated divine law and Catalan custom.

Although a unique event, the remença revolt was also one among many late medieval and early modern peasant wars. The period from the Black Death to the German Peasants' War of 1525 witnessed peasant uprisings of a greater intensity and geographical scope than in any historical era that preceded or followed. Long before 1348 , it is true, rural society was

"Anuario de listudios Medievales". 26 (1996) 
punctuated by regional insurrections such as the Stellinga Revolt in Saxony (841-842) or small revolts in particular locales such as the attempt by tenants of Darnell and Over in the north of England in the early fourteenth century to procure their freedom from serfdom by legal as well as violent means ${ }^{1}$. Most of these incidents, however, were centered around local grievances while those after 1300 were both more numerous and of greater scale and duration ${ }^{2}$. Peter Bierbrauer has counted no less than 59 peasant uprisings in the German Empire from 1336 to $1525^{3}$. The French Jacquerie of 1358, the English Rising of 1381, the German "Bundschuh" conflicts of the latefifteenth and early sixteenth centuries, and the German war of 1525 are, along with the Catalan war, the most famous large-scale conflicts. Others of significance are not as prominent in historical memory not because they were minor but because of the difficulty of the sources or the secondary literature. A major uprising in Krain (modern Slovenia) in 1515 is virtually unknown to historians of western Europe as its extensive historiography is almost entirely in Slovene ${ }^{4}$.

Not quite unknown, but certainly not fully appreciated in its comparative implications, is the Hungarian peasant uprising which took place the spring and summer of 1514. It began as a crusade against the Turks but turned into a species of holy war against the Hungarian nobility. The Hungarian war has certain features that invite comparison with Catalonia: a militarily well-organized peasantry, an unpopular ruler from a non-native dynasty, grievances centered on servitude, a revolt that did not involve (as the German, English and Bohemian cases did) a revolutionary religious

'For the Stellinga revolt, Eric J. Goldberg, Popular Revolt, Dynastic Politics and Aristocratic Factionalism in the Early Middle Ages: The Saxon "Stellinga" Reconsidered, "Speculum", 70 (1995), pp. 467-501. For the revolt of Darnell and Over in 1336 and the events leading up to it, The Ledger-Book of Vale Royal Abbey, ed. John BROWNBILL in "Lancashire and Cheshire Record Society", 68 (1914), pp. 37-42.

${ }^{2}$ Rolf KöHN, Freiheit als Forderung und Ziel bäuerlichen Widerstandes (Mitel-und Westeuropa, 11-13 Jahrhundert), "Vorträge und Forschungen", 39 (1991), pp. 325-387. An exception is the five-year war waged by Flemish peasants for which see William H. TEBRAKE, A Plague of Insurrection: Popular Politics and Peasant Revolt in Franders, 1323-1328, Philadelphia, 1993.

${ }^{3}$ Peter BIERBRAUER, Bäuerliche Revolten im alten Reich. Ein Forschungsbericht, in "Aufruhr und Empörung? Studien zum bäuerlichen Widerstand im Alten Reich", ed. Peter BLICKLE ET AL., Munich, 1980, pp. 26, 62-65.

${ }^{4}$ Studied especially by the late Bogo Grafenauer. Bibliography in GrafEnAUER, Gospodarska in druzbena zgodovina Slovencev, Ljublana, 1970, pp. 498-499 including some older works in German. 
ideology. Most curious of all, however, is that in both Hungary and Catalonia the institution of servitude was justified by reference to historical myths explaining why and when nobles and servile peasants were separated by reason of the courage of the one and the cowardice of the other. In both Catalonia and Hungary, these myths were first developed in the latter half of the thirteenth century.

Elsewhere I have tried to compare the Catalan revolt with the German Peasants' War of 1525 in order to show that a full-scale revolt did not require an anti-clerical or reform ideology ${ }^{5}$. Here I would like to extend that comparison which is intended to further a comparative understanding of the general European movement of peasant revolt in the late Middle Ages and its earlier ideological background.

\section{THE HUNGARIAN INSURRECTION OF 1514}

One of the most interesting things about the Hungarian uprising is that it demonstrates how a radical movement could be stimulated by the most traditional forms of Catholic piety. As in Catalonia, a peasant revolt was launched and justified without being accompanied or inspired by an intense attack on the established church, its doctrines or administration. The absence of a religious reform motive shows that, contrary to what is often assumed with reference to the case of Germany in 1525 , a protracted and radical peasant movement could spread without the external stimulus of urban religious unrest. Religious enthusiasm is more obvious in Hungary than in Catalonia as the insurrection began as a consequence and inspiration of what would might at first seem an archaic form of piety, a crusade.

For Hungary, occupying a beleaguered frontier with the Turks, the crusade was not an antiquated idea as it was in the West by the late Middle Ages for the Turks were an immediate peril. In the aftermath of the crucial Battle of Mohács (1526), they would conquer almost all of Hungary and occupy or indirectly control most of its traditional lands until the end of the seventeenth century. Much of the attention of the Hungarian monarchs of the fifteenth century was directed to an attempt to stem the Turkish expansion

\footnotetext{
${ }^{5}$ Dues guerres pageses: Remences catalans i camperols alemanys, "Pedralbes: Revista d'Història Moderna", 14 (1994), pp. 39-59.
} 
that accelerated after the conquest of Constantinople. A Hungarian-Polish army suffered a terrible defeat at Varna in 1444, but in the summer of 1456 a more successful crusade was proclaimed to relieve besieged Belgrade in neighboring Serbia. The crusade was preached with exceptional vigor and success by St. John Capistrano (who died shortly after its conclusion). A largely peasant army of twenty-five to thirty thousand commanded by the former Hungarian regent János Hunyadi dealt a decisive blow to the Ottoman forces and saved Belgrade. The army was quickly disbanded when the soldiers made their triumph an occasion for recrimination against the nobles, few of whom had participated in the campaign ${ }^{6}$. Under Hunyadi's son, King Matthias I Corvinus (1458-1490), not only were the Turks kept at bay, but Hungary came to control a virtual empire, extending into Austria.

The Hungarian peasantry was thus experienced in war and capable (like the Catalans but for more easily understandable reasons) of mobilizing themselves into an effective fighting force. In frontier regions such as Hungary, Styria and Carinthia where the peasantry were skilled at arms, they also were inclined during the late fifteenth century to reproach the nobility for levying exactions and taxes while abandoning their responsibilities as protectors against the infidel ${ }^{7}$.

The death of Matthias Corvinus ushered in a period of mediocre rulership and of increased power of the nobility which succeeded in radically circumscribing the authority of King Vladislav II (1490-1516), a foreigner who lacked an effective base of support in Hungary. Disputes with the nobility and a renewal of Ottoman raids led to a deterioration in the military position of Hungary. Taxes collected to strengthen the frontier were diverted by the nobles for their own purposes without effective resistance from the royal court ${ }^{8}$. In $1514 \mathrm{King}$ Vladislav promulgated a crusade proclaimed by the newly elected Pope Leo X. The crusade appears to have been the idea of the primate of the Hungarian church, Archbishop Thomas Bakócz of

\footnotetext{
${ }^{6}$ According to the account of giovanni de Tagliacozzo in Annales Minorum seu trium ordinum a S. Francisco Institutorum, vol. 12, part 3, Quaracchi, 1932, p. 793.

7Jenö SzüCS, Die Ideologie des Bauernkrieges, in Szücs, "Nation und Geschichte: Studien", Cologne, 1981, pp. 331-338.

${ }^{8}$ A History of Hungary, ed. Peter F. SUGAR ET AL., Bloomington, 1990, pp. 76-78.
} 
Esztergom, who had been a rival candidate for the papal throne and whom the amiable Pope Leo was eager to mollify 9 .

An army consisting largely of peasants was assembled in May, 1514, under the command of a frontier captain named Georgius Zeckel (or variants of that name) in the sources, but who in later accounts is usually known as György Dózsa. The forces led by Dózsa were successful against the Turks, but as in 1456, complaints arose against the apparent dereliction of the nobles. Not only had they failed to show up for the crusade but were trying to prevent their peasant tenants from leaving their lands. Dózsa's army turned its crusade into a war against the nobility. A baronial force was hastily formed to suppress the recalcitrant Dózsa and his followers but suffered defeat at Nagylak on May 24. The crusade was cancelled by the frightened king and archbishop but it was too late. During most of the month of June the peasant armies seemed triumphant. The nobles belatedly found an effective champion in the person of János Zápolya, the count (voivod) of Transylvania. In July at Temesvár (Timişoara) Dózsa's army was defeated by Zápolya and the rebellion came to an end in August. Dózsa was executed by order of the voivod by being placed in an iron throne which was then heated while he was "crowned" with a red-hot iron circlet. Dózsa's followers were then forced to eat his roasted flesh. One refused and he was instantly killed $^{10}$. This gruesome execution was the one aspect of the Hungarian revolt that would be long remembered. For Montaigne, writing seventy years after, it exemplified cruelty mingled with cowardice (although he mistakenly thought the event had taken place in Poland) ${ }^{11}$.

The aftermath of the revolt was the imposition of servitude on the Hungarian peasantry, a condition that would not be officially lifted until 1848. The authoritative law collection of 1517 , the Tripartitum drawn up by István Werböczy, justified this degradation as punishment for rebellion but

\footnotetext{
${ }^{9}$ Documents concerning the 1514 uprising are collected in Monumenta rusticorum in Hungaria rebellium, ed. Anton FEKETE NAGY ET AL., Budapest, 1979.

${ }^{10}$ Accounts of the death of Dózsa in Monumenta rusticorum, $\mathrm{n}^{\mathrm{us}} 142,153,160,200,227 \mathrm{D}$.

"Lászko BÁTI, Montaignes Aufzeichnung über György Dózsas Tod. in Aus des Geschichte ostmitteleuropäischer Bauernbewegungen im XVI-XVII Jahrhundert, ed. Gusztáv HEKENEST, Budapest, 1972, pp. 457-460.
} 
also linked it to an earlier historical crime, a supposed failure of the peasants' ancestors to fulfill their military obligations ${ }^{12}$.

\section{CATALONIA AND HUNGARY}

These events seem rather distant from Catalonia and its upheavals in the fifteenth century. Precisely by reason of a lack of direct connection, however, certain similarities demonstrate common elements in the conditions producing rural revolt at the end of the Middle Ages. There are clearly major differences between the Catalan and Hungarian revolts. The former lasted decades while the latter was over in three months. The Catalan war, although hardly to be regarded as a unilateral triumph for the entire peasant class, did result in the accomplishment of the goals of its leaders. While it did not undermine the basic structure of the seigneurial regime, the Sentencia de Guadalupe of 1486 did end the most graphic symbols of arbitrary lordship and abolished servile status. The defeat of the Hungarian peasants was complete and its results disastrous for future generations. This contrasts not only with Catalonia but with instances such as England after 1381, where despite the peasants' defeat, the revolt in the long term encouraged a gradual, unofficial decline of serfdom ${ }^{13}$.

The position of the rulers of Hungary and Catalonia was in certain respects similar. Both Vladislav II and Joan II were opposed by a nobility who could claim to be defending the customs of the nation against foreigners, the Polish-Bohemian Jagiello dynasty in one instance and the Trastàmaras in the other. Both peasants and nobles took advantage of the unpopularity of the royal government to press their claims, although in Catalonia this provoked a pact between king and peasants while in Hungary there was never any question of such an alliance. The result of the Catalan war was a victory for royal power ushering the reign of Ferdinand II and the ultimate union with Castile. In Hungary, on the other hand, the nobles solidified their supremacy as a result of the crushing of the peasant rebellion. In Werböczy's Tripartitum a virtual "republic of nobles" was sanctioned. The noble class,

\footnotetext{
${ }^{12}$ Werböczy István Hármaskönyve, ed. Sándor KoLOSVÁRI and Kelemen ÖVÁRI, budapest, 1897, part I, tit. 3, pp. 56, 58 and part III, tit. 25, p. 406.

${ }^{13}$ Werböczy István Hármaskönyve, ed. Sándor KOLOSVÁRI and Kelemen ÖVÁRI, budapest, 1897, part I, tit. 3, pp. 56, 58 and part III, tit. 25, p. 406.
} 
along with the king, was deemed to constitute the sovereign power of the state, the "crown"14. At the election of Vladislav II in 1490, the king recognized his obligations to the nobles and clergy and acknowledged that the Crown of St. Stephen lay in the custody of noble conservatores ${ }^{15}$. The peasants and other common people had no part in rulership while the king himself was only the representative of what would remain essentially an aristocratic polity until the passing of the ancien regime ${ }^{16}$.

The events and consequences of the two peasant revolts thus differed greatly, but their context and causes show certain important similarities. This is the case, above all, with regard to peasant servitude both in relation to the reasons for the rebels' discontent and the justifications offered by apologists for the nobility. I would like to focus on these issues that seem to transcend the boundaries of national histories.

\section{SERFDOM}

In both Catalonia and Hungary at the end of the Middle Ages a substantial portion of the peasantry were serfs. The Catalan remences formed more than half of the rural population in comarques of Old Catalonia and were especially numerous in the Vallès, Gironès, Empordà, La Selva, Garrotxa and Osona. Although not unknown in such comarques as the Penedès and Anoia, peasant servitude was either rare or completely absent in New Catalonia. Although servile status was never precisely nor extensively defined in law, its key characteristic was the requirement to pay a redemption fine in order to obtain freedom or change lords. The manumission payment came to be considered one among a group of "mals usos" that both symbolized the subordinated position of the remences and provided an income to lords in addition to the rent and miscellaneous exactions that comprised routine lordship over agricultural tenants.

In Hungary a majority of peasants were dependents of their lords. They are referred to in Latin documents as iobagiones, derived from the

\footnotetext{
${ }^{14}$ János BAK, Königtum und Stände in Ungarn im 14.-16. Jahrhundert, Wiesbaden, 1973, pp. $62-79$.

${ }^{15}$ Capitulatio of Vladislav II, ed. BAK, Königtum und Stände, pp. 152-154.

${ }^{16}$ History of Hungary, p. 80.
} 
vernacular (Hungarian) jobbágy ${ }^{17}$. For much of the fifteenth century, a period of expansion and relative prosperity in Hungary (very much unlike Catalonia), the lords relaxed their control over iobagiones, allowing them to take up crafts and settle in market towns. Toward the end of the century, however, a sharp rise in the value of agricultural produce induced lords to enforce prohibitions on leaving the land, to recall iobagiones from towns, and to raise rents and labor service demands ${ }^{18}$

In both Hungary and Catalonia servitude was not an age-old condition that had characterized the realm since its foundation but rather something imposed on a previously free peasantry. The chronology of enserfment was more compressed in Hungary. Although the privileges of nobles above common people were in place by the thirteenth century, the definition and enforcement of unfree status was put into effect only after the Black Death. In Catalonia the nobility may be said to have achieved certain rights and immunities with respect to comital and royal authority as early as the eleventh century, permitting them a greater power over tenants. The effective elaboration of servitude as a routine practice, however, dates from the thirteenth century.

The late Middle Ages saw a degree of high degree of instability in the relations between lords and tenants. Faced with a declining population and reduced revenues, lords throughout Europe attempted to apply more pressure to their tenants. Lords were faced with the manifestation of a latent problem in the collection of revenue within the feudal system: the peasants' effective possession of the land. As hereditary tenants of specific parcels of land, the peasants could resist seigneurial efforts at consolidation and their work for their masters was difficult to supervise. Servitude, under these circumstances, was not so much the manifestation of a violent aristocratic society but a way for landlords to increase revenue without making investments in the land or otherwise treating it as an economic enterprise.

\footnotetext{
${ }^{17}$ Peculiarly enough the word is derived from jobb meaning "better", and in the twelfth and thirteenth centuries referred to powerful men close to the king (similar to the Latin optimates). By the late fourtheenth, early fifteenth centuries it was applied to servile dependents. I am grateful to Professor János Bak of the Central European University in Budapest for this information.

${ }^{18}$ György SzÉKELY, Le passage à l'économie bassée sur la corvée en Europe centrale et orientale de l'année 1514, in "Études Historiques Hongroises 1975", 1 (Budapest, 1975); Gábor BARTA, Der ungarische Bauernkrieg vom Jahre 1514, in Aus des Geschichte ostmitteleuropäischer Bauernbewegungen, pp. 63-69.
} 
In the demographic and economic debacle that followed the Black Death, peasants who were already serfs could be forced to pay more in the way of rent or prevented from exercising an option to leave and choose among attractive vacant tenancies. There was a seigneurial reaction everywhere in Europe that attempted to salvage feudal revenues. This took different forms and met with variable success In Catalonia its short-term effectiveness is visible in the increase in redemption prices after 1348 despite (or rather because of) what would appear to have been a more favorable bargaining position for peasant labor ${ }^{19}$. Lords could, at least for a time, overcome the market forces of supply and demand (specifically, the shortage of labor) by virtue of their seigneurial power. In some instances this was backed up by the state as in fourteenth-century England where the Ordinance and Statute of Labourers $(1349,1351)$ prevented a rise in agricultural wages thus for a time defying the laws of classical economics. In England and Catalonia, unusualy among Western European nations, the late Middle Ages saw a strengthening of serfdom, but by 1500 , the institution was moribund in these countries as well as in France and Italy where it had barely survived the thirteenth century ${ }^{20}$.

Under certain circumstances lords might try to recoup their difficult economic position by offering inducements rather than by repression. In order to populate deserted manses, Catalan lords sometimes reduced rents or commuted labor and other services. The complexity of land-holding also blurred the distinction between who constituted a lord and who was a tenant in Catalonia. Emphyteusis and the various layers of leases and sub-leases created a privileged category of nominal tenant, sometimes technically unfree, who had extensive holdings on favorable terms that were cultivated by others. As already noted, until the end of the fifteenth century, Hungarian peasants, although supposedly constrained by servitude, were able to set themselves up as petty entrepreneurs in small towns established by nobles who saw revenues from that source as preferable to maintaining large agricultural domains.

\footnotetext{
${ }^{19}$ Paul FreEdman, Els origens de la servitud pagesa a la Catalunya medieval, Vic, 1993 pp. 189-190; Mercè AvENTín I PUIG, La societat rural a Catalunya en temps feudals: Vallès oriental, segles XIII-XVI, Barcelona, 1996, pp. 196-201.

${ }^{20}$ Robert BRENNER, The Rises and Declines of Serfdom in Medieval and Early Modern Europe, in "Serfdom and Slavery: Studies in Legal Bondage", ed. M.L. BuSH, Harlow, 1996, pp. 247-276.
} 
It is not always easy to measure the actual burden of a regime of exploitation such as that implicit in feudal society. This is essentially a problem of both economic reality and social perception. What was in fact being extracted by lords changed, but so did the perceptions of opportunity on the part of tenants for evasion, accommodation or departure. These did not always go in tandem. For example, the imposition of redemption payments in thirteenth-century Catalonia did not necessarily mean that peasants were unable to manipulate the system. The very frequency of such payments in surviving documents might suggest that although a burden to tenants and significant source of revenue for lords, the redemptions reflected a system of unequal but not inflexible relations between landlords and tenants ${ }^{21}$. Manumission in order to change lords might be part of the way in which land was held rather than the symbol of oppressive lordship it would become in later centuries.

The harsh economic conditions after the Black Death provoked a seigneurial reaction, not only in Hungary and Catalonia but throughout Europe. The economic changes, however, are not the sole explanation for the changes in society at the end of the Middle Ages. The same demographic and economic pressures produced very different results in different regions and these depended on political factors and the earlier forms of social organization in the respective societies.

\section{EASTERN AND WESTERN EUROPE}

One of the most significant facts of European history is the differential evolution of Eastern and Western Europe that first becomes perceptible towards the end of the Middle Ages. In the West, the attempt of lords to extract more from their tenants by either imposing serfdom or more rigid enforcement of its bonds was unsuccessful. In England, as in Catalonia, peasant revolts resulted in the decay or outright abolition of servile status. While areas of Western Europe differed as to how strong serfdom was in the high Middle Ages, how powerful the seigneurial reaction after the Black Death was, and how servitude was ended, they entered the modern era with

\footnotetext{
${ }^{21}$ Lluís To FIGUERAS, Drets de justicia i masos: Hipòtesi sobre els origens de la pagesia de remença. "Revista d'Història Medieval". 6 (1995), pp. 141-149.
} 
a seigneurial system, but one not founded on servile tenure. In France, Catalonia, indeed in most of Western Europe it is possible to regard the sixteenth century as still characterized by a feudal system of land tenure, while unusually in England there are signs of an early capitalist process of consolidation ${ }^{22}$.

The West did not share a single evolutionary path in its forms of agricultural exploitation. In England during the sixteenth and seventeenth centuries peasant proprietorship yielded to large-scale farming of a precapitalist sort while elsewhere, for the most part, small peasant holdings remained the rule. Throughout western Europe, however, in contrast with the East, the legal condition of the peasantry was free. Eastern Europe, settled by free peasants as a frontier region in the Middle Ages, would became a territory of widespread, nearly universal serfdom from the sixteenth to early nineteenth centuries. How this happened is one of the great comparative historical questions and is tied up with the differential fortunes of European states in the modern era and the problem of eastern European backwardness ${ }^{23}$. In the modern era Eastern Europe would be agricultural, dominated by large estates and characterized by either state imposed servitude (Russia) or a weak central government and virtually independent nobility (Poland, Hungary) ${ }^{24}$.

One way of explaining this disparity is to identify Western European capitalism as the motive force, creating a quasi-colonial regime in the eastern periphery in order to ensure a supply of inexpensive agricultural products and so freeing up the West for a new economic expansion. In Immanuel Wallerstein's world system, the distinction between European center and

\footnotetext{
${ }^{22}$ Aventin, La societat rural a Catalunya; Robert BrenNER, Agrarian Class Structure and Economic Development in Pre-Industrial Europe, in "The Brenner Debate: Agrarian Class Structure and Economic Development in Pre-Industrial Europe", ed. T.H. AsTON and C.H.E. PHILPIN, Cambridge, 1985, pp. 46-62; BRENNER, Economic Backwardness in Eastern Europe in Light of Developments in the West, in "The Origins of Backwardness in Eastern Europe: Economics and Politics from the Middle Ages until the Early Twentieth Century", ed. Daniel CHIROT, Barkeley, 1989, pp. 47-50.

${ }^{23}$ In general see the essays collected in "The Origins of Backwardness in Eastern Europe".

${ }^{24}$ László MaKKaI, Neo-Serfdom: Its Origin and Nature in east Central Europe, "Slavic Review", 34 (1975), pp. 225-238; Béla KIRÁLY, Neo-Serfdom in Hungary, "Slavic Review", 34 (1975), pp. 269-278; Peter GunST, Agrarian Systems of Central and Eastern Europe, in "The Origins of Backwardness", pp. 53-91.
} 
periphery is crucial to the growth of modern capitalism ${ }^{25}$. But this model consigns the Mediterranean as well as the East to the role of periphery. The Wallerstein model also suffers from a tendency to treat trade as inevitably capitalist and so assumes that the governing classes of sixteenth-century Europe acted to maximize economic efficiency as a universal and unquestioned goal.

Almost all of Europe experienced the catastrophe of the Black Death and the successive plagues, yet the two halves would be sharply differentiated as regards serfdom. Similarly, the expansion of trade in such commodities as textiles, cattle and above all grain could produce very different social results. The different experiences, especially between East and West, demonstrate the limitations of purely demographic or economic explanations of social change. Class relations and the power of nobles or the state produced outcomes other than what would be predicted by the impersonal interaction of supply and demand ${ }^{26}$.

Hungary might seem to exemplify the experience of the East: the imposition of servitude in the late medieval and early modern eras, and the assertion of nobles' power at the expense of the king and the peasantry. Catalonia would then fit into the Western model with the overthrow of serfdom. Peasant small-proprietorship was preserved in Catalonia, and so the abolition of servitude did not lead to the capitalist agricultural organization that characterized England ${ }^{27}$. But the contrast between Catalonia and Hungary is not as neat or dramatic as simple geographical typologies of development would suggest. Hungary in the early modern era would not be an exporter of grain to the West on the order of Poland or eastern Germany. Its main product would be livestock and its market the somewhat fading towns of southern Germany, not the dynamic Atlantic regions ${ }^{28}$. Moreover so much of Hungary's medieval lands passed into Ottoman hands that its

\footnotetext{
${ }^{25}$ Immanuel WaLLERSTEIN. The Modern World System, vol. I: Capitalist Agriculture and the Origins of the European World Economy in the Sixteenth Century, New York, 1974.

${ }^{26}$ See Marian MALOWIST, Le commerce de la Baltique et le problème des luttes sociales en Pologne aux $X V^{\prime}$ et $X V I^{\prime}$ siècles, in "La Pologne au $\mathrm{X}^{\mathrm{e}}$ Congrès International des Sciences Historiques à Rome", Warsaw, 1955, pp. 126-146; Jerome BLUM, The Rise of Serfdom in Eastern Europe, "American Historical Review", 62 (1957), pp. 807-836.

${ }^{27}$ But in this regard it is England, not Catalonia that was the exception and the historical problem is not to explain economic stagnation but the more unusual take-off experienced by England, BRENNER, Economic Backwardness in Eastern Europe, pp. 15-20; 47-50.

${ }^{28}$ GunST, Agrarian Systems, pp. 70-72.
} 
experience stands between that of the Turkish occupied Balkans and the vast regions of estates and servitude of northeastern Europe ${ }^{29}$.

Rather than looking at them as examples of opposite or complementary regional evolution, we might examine the peculiar similarities of Hungary and Catalonia in the period of peasant uprisings. What they shared at the end of the Middle Ages was a society deeply divided about the legitimacy of servitude. Not only did peasants agitate for the end to arbitrary seigneurial control in both realms, but the need of the lords to justify the institution of servitude would take similar forms.

\section{HistoRiCAL MYTHOLOGY \\ AND THE ORIGINS OF SOCIAL DIFFERENTIATION}

In both Hungary and Catalonia (more so in Hungary), serfdom was a relatively recent institution, one that was not easily explicable in terms of customary law and practice. Historical myths were elaborated to put back into authoritative and distant time the division of society into servile and noble. More than this, both societies had to explain subordination of one segment of the nation by another. In some regions of Europe it was possible to justify servitude by virtue of conquest. Thus the Catalans in Greece or Sardinia might hold the native population in some form of subjugation by victory in war. Elsewhere myths of differential origins were devised even in the absence of ethnic or linguistic distinction. In France serfs could be regarded as descendants of the conquered Gauls while the nobles' ancestors were the Franks ${ }^{30}$.

In Catalonia the fundamental division of society was placed at the time of the Carolingian conquest of the Spanish March. The Franks (sometimes specifically Charlemagne or Louis the Pious) called on the Christian inhabitants of the future Catalonia to rise up against the Moors.

\footnotetext{
${ }^{29}$ See BRENNER'S typologies in Economic Backwardness in Eastern Europe, pp. 40-50.

${ }^{30}$ Susan REYNOLDS, Medieval "Origines gentium" and the Community of the Realm, "History", 69 (1984), p. 384. As Reynolds notes tracinig different classes to different racial genealogies was more popular after 1500 than during the Middle Ages.
} 
Those who out of timidity refused were kept in the servile status they had accepted under the infidel, but now to be ruled by Christians ${ }^{31}$.

This legend is first found in legal commentaries perhaps as early as the late thirteenth century and became widely although not universally accepted among historians during the late-medieval and early modern periods. It had the advantage of placing the invention of serfdom in the deep past, at the time of the foundation of Catalonia. It therefore sanctioned servitude as a custom of equal age with the polity itself.

Even more, the legendary account in effect acknowledged that servitude was contrary to the natural liberties of Catalans but nevertheless justly separated the remences from those worthy of enjoying those freedoms. It functioned as a secular version of the hereditarily transmitted punishments in the Bible such as Adam's Fall or the Curse of Noah against Ham. Without denying that the servile population was ethnically Catalan, the myth of the peasants' cowardly ancestors explained why they were treated as if they were a conquered and captive people.

As a complement to this justification for serfdom, the legend of Otger Cataló, fully developed at the opening of the fifteenth century, explained the privileges of the nobility ${ }^{32}$. The aristocratic families of Catalonia were descended from those who aided Otger Cataló, a warrior who waged a guerilla war against the Muslims in the Pyrenees before the Franks invaded. The nobles, therefore, and not the Franks or the counts of Barcelona were the true founders of Catalonia. Here there is a similar although less successful attempt to that of the Hungarian nobility to make their order the repository of the nation's political identity and source of its government. At the same time, the legend of Otger implicitly fits that of the origins of peasant serfdom. Those who aided or even came before Charlemagne in fighting the enemy were to be privileged and exalted in the future history of Catalonia, while those who failed this moment of testing would be serfs, along with their descendants.

\footnotetext{
${ }^{31}$ I have discussed these legends in Juristes catalans $i$ els origens de la servitud, in Paul FREEDMAN, Assaig d'història de la pagesia catalana (segles XI-XV), Barcelona, 1988, pp. 172 181 and Cowardice, Heroism and the Legendary Origins of Catalonia, "Past and Present", 121 (1988), pp. 3-29.

${ }^{32}$ Miquel Coll I Alentorn, La llegenda d'Otger Cataló $i$ els Nou Barons, "Estudis Romànics", 1 (1947-1948), pp. 1-47.
} 
In Hungary one finds a very similar historical/mythical justification for servitude. As in Catalonia, unwillingness to risk warfare was set in the foundational past in order to account for social difference. It was supposed that in pre-Christian times the Magyars held an annual military muster and that failure to attend was punished by death, banishment or hereditary servitude. Those of lower condition were descended from Hungarians who had failed this test of valor.

For Hungary the introduction of the legendary origins of serfs can be pin-pointed more precisely than for Catalonia. Between 1282 and 1285 Simon of Kéza, court chaplain to King Ladislas "the Cuman," composed a Hungarian history that elaborated a heroic past ${ }^{33}$. His primary interest was to justify the prerogatives of nobles rather than to explain servitude, which was only in its first stages of development. His fanciful explanation for the distinction between nobles and common people, nevertheless, would be useful for subsequent generations to explain where the Hungarian iobagiones came from.

Much in the manner of the Catalans, the Hungarians made use of literary and historical narratives to connect themselves to a heroic European past. Charlemagne and his conquests joined the Catalans to the imperial and Frankish mainstream. For the Magyars, the authoritative figures of the past were the Huns ${ }^{34}$. Although we were accustomed to thinking of the image of the Huns as entirely negative or destructive, they are portrayed favorably in such medieval works as the German Nibelungenlied (ca. 1200). By this time the Magyars, whose destructive invasions took place in the tenth century, were confused with the real Huns of Late Antiquity (whence "Hungarian").

Simon of Kéza was the first Hungarian chronicler to accept the Western belief that the Magyars were descendants of the Huns. In the year 700, according the Gesta Hungarorum, the Huns elected captains and began their movement westward from "Scythia". Their leader was a certain Kadar

\footnotetext{
${ }^{33}$ Simon de KÉZA, Gesta Hungarorum, ed. Alexander DomanovSKY, in "Scriptores Rerum Hungaricum", vol. 1, Budapest, 1937, c. 7, pp. 147-148.

${ }^{34}$ On the Hungarian legends of the origins of nobility and servitude I have relied Jenö SzüCs, Theoretical Elements in Master Simon of Kéza's "Gesta Hungarorum" (1282-1285 A.D.), in "Études Historiques Hongroises 1975", vol. 1, pp. 241-281 and Richard C. HoffmanN, Outsiders by Birth and Blood: Racist Ideologies and Realities around the Periphery of Medieval European Culture, "Studies in Medieval and Renaissance History", new series, 6 (1983), pp. 14-21.
} 
who developed a program to form an army. A customary law was established that a summons would be issued annually to a military gathering of the able-bodied male population. Those who failed to attend without good reason would be subject by the "Lex Scitica" either to execution by being cut with a plowshare, degradation by means of banishment, or reduction to the status of $\operatorname{serf}^{35}$.

Simon concludes with a formulation of the problem answered by his history: it was his own wicked actions that differentiated one Hungarian from another, for otherwise how to explain why those sharing the same parentage should be noble and ignoble? The latter's ancestors must have perpetrated some crime ${ }^{36}$.

So far the distinction is simply between nobles and everyone else, but later historians and jurists would use this passage to justify the servitude of some Hungarians and the privileges of others. In the Chronica Hungarorum of János Thuróczy, the Hunnish military laws originated the separation of nobles from serfs ${ }^{37}$. Thuróczy repeats Simon of Kéza but adds a few details. The summons to the muster is now made by a messenger bearing a bloody sword (a practice that actually accompanied the calling up of Transylvanian frontier soldiers in the late Middle Ages). Thuróczy also specifically states that by means of the muster and the punishment for failure to attend many had been degraded to perpetual rusticity (et multos generatione de hac perpetuam redegit in rusticitatem). The concluding rhetorical question now asks: "for as they were of one and the same birth... how else could it be that one could be a lord, another a serf or peasant? ..."38 Thuróczy's Chronica reflects the seigneurial pressures of the late fifteenth century in its assumption that serfs and rustics are the same thing.

\footnotetext{
${ }^{35}$ Gesta Hungarorum, c. 7, pp. 147-148: "Quicunque ergo edictum contempsisset praetendere non valens rationem, lex Scitica per medium cultro huius detruncabat, vel exponi in causas desperatas, aut detrudi in communium servitutem". On the meaning of "exponi in causas desperatas", a formulation derived from Roman law, see Szücs, Theoretical Elements, pp. 268-269.

${ }^{36} I$ Ibíd. c. 7, p. 148: "Vitia itaque et excessus huius unum Hungarum ab alio separavit, alias cun unus pater et unus mater omnes Hungaros procreaverit, quorum unus nobilis, alter innobilis diceretur, nisi victus per tales casus criminis haberetur".

${ }^{37}$ Johannes de THURÓcz, Chronica Hungarorum, ed. Elisabeth GaLÁNTAI and Julius KRISTÓ, vol. 1, Buidapest, 1985, c. 12, pp. 33-34.

${ }^{38}$ Ibid., p. 34: "Nam cum una et eadem fuerint generatio, et a quondam Hunor et Magor unanimiter processerint, aliter fieri nequivisset, ut alter dominus, alter servus vel rusticus effici potuisset".
} 
In an example of the power of pseudo-historical narrative to influence social reality, this version of foundational events and justification for servitude was put into effect after the failed insurrection of 1514 . Legislation in November of that year condemned the rebellious populace to "perpetual rusticity" (dominis ipsorum terrestribus mera et perpetua rusticitate sint subiecti), echoing Thúroczy's formulation ${ }^{39}$. Very similar wording appears in the Tripartitum. Here the degradation of peasants is explained as a consequence of the recent rebellion but also in terms of the customs of the early Hungarians. The nobles were privileged because their ancestors answered the military summons ${ }^{40}$. The differentiation between lords and serfs (and between nobles and ignobles or rustics) originated at this time according a statement derived from Simon of Kéza via Thuróczy ${ }^{41}$. Thus in the Tripartitum there is a short-term explanation for the subordination of the peasantry (the events of 1514) and a long-term one (the responses to the Huns' military customs). Werböczy also asserts that the populus of Hungary, in whom resides the power of the Hungarian Crown, consists of the nobles and not the peasants, a statement reminiscent of Gabriel Turrell's assertion made in 1476 that Charlemagne established Catalan liberties for those of high birth, not rustics ${ }^{42}$.

\section{Historical Myths and IdEOlogical PURPOSE}

In both Hungary and Catalonia, therefore, the defense of servitude was maintained by reference to very similar myths of national origin. At a formative moment one segment of the population showed itself courageous and therefore worthy of liberty. In Catalonia this courage was demonstrated against the Moors in a species of religious war that was also a battle of national liberation. In Hungary the fundamental division reflected pre-

\footnotetext{
${ }^{39}$ Monumenta rusticorum in Hungaria rebellium, $\mathrm{n}^{\circ}$ 202, article 14, p. 260.

${ }^{40}$ Werböczy István Hármaskönyve, part. 1, tit. 3, pp. 56, 58.

${ }^{41} I$ bid., part 1, tit. 3, p. 58: "Haec sanctio plurimos Hungarorum (ut praefertur) plebae perhibetur effecisse condicionis. Nam cum una et eadem de generacione unanimiter processerint, aliter fieri nequivisset, ut hic dominus, ille servus, hic nobilis, ille ignobilis, et rusticus efficeretur".

${ }^{42}$ Gabriel TURrell, Recort, cit. Coll I Alentorn, Llegenda d'Otger Cataló, p. 27; "E aquest és lo principi de les llibertats de Cathalunya, car no principia en hòmens rústichs ni aplegadiços, sinó en alts e valerosos".
} 
Christian custom and law set in the supposedly authoritative time of the Huns.

Many medieval states developed heroic myths of their beginnings, but in Hungary and Catalonia these legendary origins also served to explain class structure. The birth of the polity and the identity of the people coincided with a definition of those who were privileged and free and those inhabitants deprived of rights and of liberty. These stories of national and class foundations combine already-existing legends with ideas found in the French literary tradition, specifically the cycle of poems elaborated around the figure of Charlemagne. In Catalonia the legend of the cowardly peasants was probably derived from France via the heroic Latin chronicles purporting to be by Archbishop Turpin of Rheims, known in Catalonia as early as 1173. Here and in related invented histories, serfs who aided Charlemagne were rewarded with freedom while free men who shirked their obligations were condemned to servitude ${ }^{43}$. The idea of relating servitude to failure to obey a military summons appears in many medieval contexts ${ }^{44}$. The particular role of Charlemagne, however, originates with Pseudo-Turpin and would be elaborated on in the thirteenth and fourteenth centuries in such French poems as the Chanson de Gui de Bourgogne and the Roman de Renart le Contrefait ${ }^{45}$.

The origin of the Hungarian legends is somewhat less clear, although their development can be located chronologically more precisely than for Catalonia. Before Simon of Kéza's Gesta Hungarorum there was a tradition of national mythology in chronicles, but as already mentioned, Simon was the first Hungarian to make use of the putative connection between the Magyars and the Huns. Simon travelled in France and Italy and was familiar

\footnotetext{
${ }^{43}$ On the Pseudo-Turpin and its aristocratic audience in France, see Gabrielle M. SPIEGEL, Romancing the Past: The Rise of Vernacular Prose Historiography in Thirteenth-Century France, Berkeley, 1993, pp. 55-98. The reception of the Pseudo-Turpin material in Catalonia, Adalbert HÄMEL, Arnaldus de Monte und der Liber S. Jacobi, "Estudis Universitaris Catalans", 21 (1936), pp. 147-159; História de Carles Maynes e Rotllà: traducció catalana del segle XV, ed. Martí de RIQuer, Barcelona, 1960. See also Gerhard RaUSCHEn, Die Legende Karls der Grossen im 11. und 12. Jahrhundert, Leipzig, 1890, pp. 97-125, especially p. 108.

${ }^{+H}$ Henry LEMAITRE, Le refus de service d'ost et l'origine du servage, "Bibliothèque de l'École des Chartes", 75 (1914), pp. 231-238.

${ }^{45}$ Gui de Bourgogne, vv. 177-180, ed. F. Guessard and H. Michelant, Paris, 1859 , p. 6: Le Roman de Renard le Contrefait. ed. Gaston REYNAUD and Henri Lemaitre, vol. 1, Paris, 1914, p. 353.
} 
with Roman law, French romance and Latin literature ${ }^{46}$. Other than the barbaric form of execution (being cut in half), the punishments for failure to attend the Huns' muster are derived from Roman law. In addition Simon was probably induced by the same French literary and quasi-legal tradition that influenced Catalonia to legitimate noble privilege over common people by reference to military courage in the distant past.

Why were such elaborate justifications necessary? To some extent this question is related to the reason why these legends had so much more resonance in Catalonia and Hungary than in France, their place of origin. In France servitude declined from the thirteenth to fifteenth centuries. In certain French regions (especially the West), servitude had never been strong. In Languedoc it simply ceased to be important by the thirteenth century, partly as a result of the collapse of the nobility in the wake of the Albigensian Crusade. In the central regions of France, peasants were encouraged to purchase their freedom from the crown ${ }^{47}$. In Catalonia and Hungary, servitude not only increased in the late Middle Ages, but became an issue sufficiently divisive to create civil war.

There are three factors that Hungary and Catalonia share with regard to what might be called the intellectual context of servitude: 1) servitude could not readily be explained by an appeal to obvious customary law and practice; 2 ) there was no convenient way of assuming different ethnic origins for servile and noble populations; 3 ) the audience or "consumers" of historical legends were not exclusively antiquarian or literary writers but lawyers and others concerned with defending existing institutions.

The purpose of the legendary origins of privilege and serfdom was to exalt the heroism of the nation while defining only a minority of its inhabitants as its true constituents. In other countries conquest or ethnic and religious difference could be used to explain subordination ${ }^{48}$. The English in Ireland excused their subjugation of the inhabitants on the basis of their alleged barbarism, on rights based on conquest and later on religious difference. The Catalans in Athens also could justify dominating the native population on the basis of religious heterodoxy and the fact of conquest.

\footnotetext{
${ }^{46}$ Szücs, Theoretical Elements, pp. 251-252, 268-269, 278-280.

${ }^{47}$ William CheSter JORDAN, From Servitude to Freedom: Manumission in the Sénonais in the Thirteenth Century, Philadelphia, 1986.

${ }^{48}$ Robert BARTLETT, The Making of Europe: Conquest, Colonization and Cultural change, 950-1350, Princeton, 1993, pp. 85-105.
} 
What stands out for Hungary and Catalonia is that no attempt was made to suggest that the servile population was different in its ethnic origins and identity from the nobles. What made one a "real" Hungarian or Catalan as opposed to a serf was based on a historic moment of foundation, not a difference in the blood.

The lack of such "racial" distinction made it more difficult to maintain the justice of subjugation with complete confidence than in conquered territories or those places with populations of manifestly different origins. Catalan jurists (notably Tomàs Mieres), and members of the royal court (such as Queen Maria de Luna) expressed grave doubts over whether the treatment of remences could be reconciled with legitimate custom or divine and natural law ${ }^{49}$. Objections in Hungary were more the province of religious critics of society, especially members of the Observant wing of the Franciscans who were especially active before and after 1500 , some of whom were even involved in the rebellion of $1514^{50}$.

In both realms peasants themselves could justify their revolt by reversing the rationales for subordination and aristocratic privileges. In Catalonia the formation of syndicates of remences in 1448-1449 provided an occasion to dispute the nobles' myth ${ }^{51}$. It was argued that the ancestors of the remences had been not timid Christians but rather Muslims, and that servitude was instituted to encourage conversion, not as a perpetual sentence. Once the conversion to Christianity took place, servitude should have been voided, but this the lords, through selfish greed, had not done. While it is unlikely that any Catalan peasant was in fact eager to claim Muslim ancestry in the fifteenth century, the argument was an ingenious response to the myth of the cowardly ancestors of the remences.

In Hungary it was the code of bravery and its link to freedom that was appropriated by peasants and their apologists in 1514. Accepting the

\footnotetext{
${ }^{49}$ Antoni RIERA I MELIS, El bisbat de Girona al primer terç del segle XV. Aproximació al context socio-economic de la sèrie sísmica olitina (1427-1428), "Anuario de Estudios Medievales", 22 (1992), pp. 161-204; Fidel FITA, Lo papa Benet XIII y los pagesos de remensa, "La Renaxensa", 5 (1875), pp. 122-130; FREEDMAN, Orígens de la servitud pagesa, pp. 203214.

${ }^{50}$ Jenö Szucs, Oppositionelle Strömung der Franziskaner im Hintergrund des Bauernkrieges und der Reformation in Ungarn, in "Études Historiques Hongroises 1985", vol. 2, Budapest, 1985 , pp. 483-512. 249.

${ }^{51}$ Discussed in FrEEDMAN. Origens de la servitud pagesa, pp. 211-212 and edited pp. 247-
} 
equation by which military courage provided the moral basis for liberty, the peasants not only proclaimed themselves the sanctified defenders of Hungary and of Christendom against the Turk but plausibly condemned the nobility for failing to aid the crusade. The nobles failed to perform their role as a warrior class for which they received their privileges. Moreover, this failure contrasted with the bravery of the peasants who thus threw back at their masters the accusation of cowardice. The bloody sword mentioned in Thuróczy's chronicle as an emblem of the Huns' military summons was used by the peasant crusaders in their recruitment, a clear message about their courage and an implied denunciation of the nobility for failing to uphold the fidelity that they were supposed to render by Hungarian constitutional tradition.

Counter-myths and condemnation of the nobles' greed and military failure functioned as what Guy Marchal in the context of Swiss history has called "the answer of the peasants" to widely-diffused seigneurial justifications for domination ${ }^{52}$. In Switzerland and along the North Sea coast there were independent peasant republics in the Middle Ages that managed to hold off efforts by princes and nobles to conquer them ${ }^{53}$. Nothing comparable to the war-songs of the Swiss cantons or the Dithmarschen peasants survives for Catalonia or Hungary where there was of course no question of peasants gaining political autonomy. Nevertheless the same exaltation of piety mingled with courage and the same condemnation of the nobility for its arrogance and exaggerated sense of self-worth may be found at different ends of Europe. In Catalonia, Hungary as well as England and Germany, forms of resistance developed within the traditions of peasant society without requiring an external intellectual stimulus from towns or church reform movements.

Let us return for a moment to the geographical distribution of servitude in the transition from the medieval to modern era. Robert Brenner's essays have shown the limitations of a simple East/West distinction and also demonstrate that the West did not pursue a course

\footnotetext{
${ }^{52}$ Guy P. MARChaL, Die Antwort der Bauern: Elemente und Schichtungen des eidgenössischen Geschichtsschreibung und Geschichtsbewusstsein am Ausgang des Mittelalters, "Vorträge und Forschungen", 31 (1987), pp. 59-90.

${ }^{53}$ Peter BLICKLE, Das Gesetz der Eidgenossen: Überlegungen zur Enstehung der Schweiz, 1200-1400, "Historische Zeitschrift", 255 (1992), pp. 561-586; William L. URBAN, Dithmarschen: A Medieval Peasant Republic, Lewiston, 1991.
} 
leading inevitably to a capitalist economy until the relatively recent past. Outside of the important exception of England, there was considerable continuity in the West between the medieval period and the sixteenth and seventeenth centuries. Both eras were characterized by predominantly agrarian societies organized into small units cultivated by peasant proprietors under a regime of extra-economic extraction. Servitude was declining or irrelevant except in those territories (notably Catalonia) where it was thrown off by force.

In eastern Europe, apart from regions conquered by the Turks, servitude was extended in the late medieval and early modern centuries. Hungary thus conforms to a pattern, but its experience provokes certain questions about why serfdom triumphed. As already noted, Hungary did not produce grain or other basic agricultural commodities for the Western market (largely because of the prohibitive cost of transportation in comparison with the water-borne traffic of Poland and eastern Germany). Neither can servitude in Hungary readily be explained by the absence of village communities among peasants ${ }^{54}$. Not only does the 1514 insurrection show the strength of peasant solidarities in hungary, but conversely the success of the Catalan revolt can not be traced to an unusually strong sense of community. The dispersed habitat of Old Catalonia and the absence of formal local bylaws (on the order of the German Weistümer) did not prevent the formation of syndicates of remences in the fifteenth century and of military units supported by villagers at the time of the Catalan Civil War.

The different outcomes of the Catalan and Hungarian conflicts are thus not to be explained in terms of an inevitable contrast between the two halves of Europe. The situations in the fifteenth century were quite similar. A weak monarchy, a seigneurial reaction, and an elaborate seigneurial justification for serfdom characterized both principalities. The particular circumstances of each nation affected the fate of the uprisings, especially the political circumstances. The Catalan monarchs, although in great difficulty, inherited a stronger constitutional tradition of authority. They also allied themselves, albeit inconsistently, with the peasants. Even with the support of elements of the city of Barcelona, the Catalan nobility was unable to maintain the servile system. In Hungary, the conflict between nobles and

\footnotetext{
${ }^{54}$ Which BRENNER uses as a hypothesis, "Agrarian Class Structure and Economic Development", pp. 40-41.
} 
king was subsumed by the shared fear of the peasants. Although supported by elements of the Franciscan order and led by a few members of the petty nobility, the peasants of Hungary in 1514 lost in their attempt to portray themselves as faithful patriots. The overwhelming impression of the chroniclers and in messages exchanged among Hungarian nobles and officials was one of common terror at the supposed bloodthirsty savagery of the rebels, something one does not see in Catalonia, England or even to the same extent in Germany in 1525 .

Neither in Catalonia nor in Hungary was there an inevitable outcome to the conflict over serfdom. The history of the two conflicts confirms Brenner's emphasis on the importance of ideology and political structures in the transition to from feudalism to modernity.

\section{RÉSUMÉ}

En Hongrie, comme dans la Catalogne, il y eut un grand soulèvement des paysans au fin du Moyen Âge. La révolte hongroise de 1514 fut suprimé par la noblesse, mais les paysans catalans effectuèrent l'abolition du servage en 1486. Malgré cette divergence éssentielle, on peut constater quelques ressemblances entre les deux pays, surtout à l'egard des justifications idéologiques pour le servage et les condamnations à l'encontre le servage.

La fondation pour ce conflit idéologique remont au treizième siècle quand les mythes historiques de l'établissement de la nation étaient en procès d'élaboration, basés sur le cycle littéraire français "Pseudo-Turpin". Pour la Catalogne, l'époque carolingienne fut convenable pour justifier les privilèges nobiliaires et la subjugation de la paysannerie, hiérarchie basé sur le courage, d'un côté, et la couardise, à l'autre, pendant les guerres contre I'Islam. En Hongrie, une épreuve similaire située dans les temps de la fondation nationale expliquèrent pourquoi les aristocrats dominèrent les paysans, mais c'était les Huns, ancêtres supposés des Magyars, qui fournirent le contexte historique. Dans les deux cas, les genres littéraires étaient adoptés pour servir des théories, juridiques et historiographiques lancées comme preuves de la justice du servage. On peut aussi tirer des indications pour le Bas Moyen Âge des réponses des paysans et leurs defenseurs contre ces mythes historiques.

\section{SUMMARY}

Both Catalonia and Hungary experienced major peasant uprisings at the end of the Middle Ages. The Hungarian Revolt of 1514 was suppressed by the nobility while the Catalan peasants succeeded in throwing off servitude in 1486. Despite this fundamental difference, 
there are certain ideological similarities between Hungary and Catalonia, particularly with regard to the ideological justifications for servitude and attacks against it.

The background to this ideological conflict goes back to the late thirteenth century when historical myths of foundation were elaborated in both countries based on the French Pseudo-Turpin cycle. In Catalonia, the Carolingian era provided a suitable background to explaining the privileges of nobles and the subordination of the peasantry based on courage and cowardice aganist the Muslim enemy. In Hungary, a similar test of bravery placed in early times explained why nobles dominated over the peasantry, but the historical context was now the supposed Hunnish ancestors of the Magyars. In both instances literary forms were taken over by historians and jurists to explain and justify servitude. We also have some idea from the late Middle Ages of how these assertations were answered by advocates of the rebellious peasantry. 